\title{
Objetividade e credibilidade midiática: reflexões sobre uma suposta conexão
}

\author{
René Seidenglanz, Liriam Sponholz'
}

\begin{abstract}
Resumo: As informaçòes transmitidas pela midia têm credibilidade porque são corretas ou são „corretas“ porque acredita-se que sejam? Credibilidade pode ser reduzida a objetividade? Até que ponto existe uma relação entre objetividade e credibilidade e que tipo de relação é esta? Os autores desenvolvem aqui a tese de que credibilidade é determinada por uma série de fatores, dentro da qual a adequação das informações à realidade tem um papel secundário. Além disso, determinados rituais de objetividade como neutralidade e fairness (o princípio de ouvir os dois lados) podem contribuir para dar credibilidade, mas não estão necessariamente ligados à adequação de uma cobertura jornalística à realidade.
\end{abstract}

Palavras-chave: Objetividade. Realidade. Conhecimento. Credibilidade. Jornalismo.

Abstract: Is the information delivered by the media believable because it is true, or is it "true" because it is believed? Can credibility be reduced to objectivity? How and to what degree are objectivity and credibility related? The present article attempts to address these questions. The authors present the thesis that the problem of credibility is dependent on a variety of factors, among which the information's accordance with reality is subordinate. While the media's implementation of certain rituals of objectivity such as neutrality or fairness can serve to establish credibility, they are not necessarily connected with the accordance with reality in coverage.

Keywords: Objectivity. Reality. Knowledge.Credibility. Journalism.

\section{Introdução}

A relação entre objetividade e credibilidade na discussão científica sobre o tema tem sido até o momento mais pressuposta do que examinada. Além disso, ambos os conceitos raramente são definidos em estudos empíricos, o que dificuita muito uma investigação com base em critérios intersubjetivos. Desta maneira, os resultados das pesquisas realizadas se resumem freqüentemente à conclusão de 
Para Bentele (2008), a questão é obter resultados sobre aspectos mais profundos da questão da credibilidade midiática ao levantá-los não somente com relação ao meio de comunicação, mas também com relação ao veículo ou programa escolhido. Neste sentido, as diferenças entre credibilidade intramidiática podem ser maiores do que a entre os meios. Nestmann (1980: 116) constatou com relação à $T V$ que programas podem ser avaliados de maneira mais positiva do que o meio em si, o que mostra que esta diferenciação faz sentido. Uma série de trabalhos anteriores fizeram o mesmo analisando a credibilidade de jornais e canais de TV locais (cf. Abel/Wirth, 1977)'

De maneira geral, pode-se dizer que "credibilidade midiática" pode ser atribuída a objetos muito diversos e resultar respectivamente tanto em conceitos quanto mecanismos diferentes de atribuição. $O$ conceito pode conseqüentemente ser analisado em níveis distintos.

Baseando-se em Wirth $(1999,54)$, pode-se diferenciar dois níveis de análise, o do conteúdo ou mensagem concretamente e sua apresentação de um lado e o nivel de mediação e do mediador, que podem ser claramente separados considerando-se os diferentes aspectos da atribuição de credibilidade. Esta pode ser conferida a textos, ou seja, a o quê está sendo apresentado ou comunicado ou a quem apresenta ou comunica algo.

O meio de comunicação recebe uma posição especial neste modelo. Este é entendido como o modo de apresentação, ou seja, como se comunica (visual, auditivo, audiovisual) e é classificado dentro dos conteúdos midiáticos. Sua apresentação é entendida como parte da mensagem.

Por outro lado, meios podem ser entendidos como parte das instituições de mediação, como por exemplo televisão como o conjunto dos canais. Quando se trata de credibilidade, ambos podem ser importantes, mas aqui prefere-se o entendimento de meios como modo de apresentação (veja gráfico 1).

A investigação de credibilidade midiática baseada unicamente no meio de comunicação (televisão, rádio, jornal ou revista) já foi criticada várias vezes. Não se confere credibilidade à televisão ou à revista, mas sim a um determinado canal ou uma determinada revista. O meio como o único objeto de credibilidade midiática e conseqüentemente de investigação é problemático a priori quando o meio é entendido como a categoria geral dentro da qual as instituições midiáticas são organizadas. Isto é questionável se for considerada a heterogeneidade, que abrange desde o programa de entretenimento até o canal com temas específicos.

O ponto de investigação relevante para a credibilidade midiática se encontra na apresentação dos conteuidos específica de cada meio (cf. Christofoletti e Laux, 2008). Por isso, apesar da crítica, a diferenciação de credibilidade de acordo com o meio é indispensável. A imprensa tem uma outra recepção do que o rádio ou 
a TV, o que influencia a credibilidade que the é conferida. A televisão tem uma credibilidade maior do que a imprensa, pois aquela dá ao receptor a impressão de que os acontecimentos podem ser controlados por causa das possibilidades de visualização (Bentele, 2008).

Ao lidar com a mídia, são os conteúdos que interessam ao receptor e que oferecem a possibilidade de integração de ações e mudanças de atitude. Como conteúdos entende-se os acontecimentos ou fatos apresentados. Pertencem a eles atores como políticos ou empresários, cujas declarações ou ações fazem parte das mensagens midiáticas, mas que não pertencem ao sistema midiático. $O$ conceito de credibilidade midiática envolve com isso basicamente a credibilidade da apresentação, que deve ser diferenciada daquela dos atores apresentados.

A credibilidade dos textos, do seu conteúdo, depende das características do texto, sobretudo de até que ponto percebe-se contradições entre os seus elementos e entre declarações diferentes. Também neste caso deve-se diferenciar entre as contradições do ator apresentado no texto e do texto próprio. Se uma notícia apresenta contradições entre as declarações de um ator, esta é uma questão de credibilidade do autor, e não do conteúdo midiático. Para a credibilidade do texto, o relevante é o último, ou seja, incoerências dentro de um texto ou entre textos diferentes. Além disso, o decisivo é até que ponto o receptor percebe tais contradições.

A credibilidade dos conteúdos ou das formas de apresentação destes por um lado e da dos diferentes níveis de mediação, responsável pela transmissão dos conteúdos de outro lado, se influenciam reciprocamente. A credibilidade do comunicador condiciona a priori a de um conteúdo concreto.

Com relação às instâncias de mediação, pode-se diferenciar diferentes camadas ou níveis, aos quais credibilidade pode ser conferida: pessoal, institucional e do sistema. Este conceito considera o resultado do desenvolvimento histórico, da constituição e da profissionalização da mídia. Desta forma, o elemento de uma camada parte da anterior, aumentando a complexidade e abstração.

A separação clássica entre pessoa, instituição e sistema" é necessária para uma classificação dos possiveis de credibilidade midiática porque, dependendo do grau de abstração, alguns mecanismos de atribuição de credibilidade se tornam mais relevantes do que outros. A credibilidade de uma determinada pessoa se baseia em aspectos diferentes do que a avaliação de instituições ou sistemas.

A credibilidade das pessoas na mídia pode ser identificada como a camada mais concreta. No caso da credibilidade concedida "cara a cara", a semelhança que o receptor pensa ter com o personagem da mídia é um destes fatores. Esta semelhança tem sido investigada sobretudo com relação à semelhança cultural

8 Un telespectador pode acompanhar o que acontece nas telas, ou pelo menos acredita nisto. Ele pode participar diretamente do acontecimento. A característica da visualidade, específica deste meio, tem um papel altamente relevante para a atribuição de credibilidade.

9 Esta classificação é feita também por Bentele (1994a: 143) com relação ao problema da confiança 


\section{Credibilidade midiática e objetividade}

Objetividade tem sido analisada como um dos componentes da dimensão "trutsworthiness" nos estudos voltados para a análise multidimensional de credibilidade (cf. entre outros Mosier e Ahlgren, 1981). Hovland, Janis e Kelley (1953), por sua vez, ordenaram o fator de objetividade ao lado do conceito de honestidade (bonesty). Já Whitehead (1968), Iyengar e Kinder (1985) e Austin e Dong (1994) investigam objetividade como um componente separado de credibilidade.

Caso deva-se formular uma relação de causalidade entre credibilidade e objetividade, considerando-se as pesquisas já realizadas, faz sentido postulá-la na direção da objetividade - como o receptor a percebe - para a credibilidade.

Neste contexto, Bentele (2008: 248) constata uma correlação entre determinados "standards de objetividade" na mídia e na cobertura jornalística e a credibilidade destas publicações junto à população. Nos casos das publicações em que há um alto grau de julgamentos feitos pelos próprios jornalistas, observa-se um grau de credibilidade tendencialmente mais baixo. Bentele (2008) cita sinais concretos que são interpretados pelo receptor como falta de objetividade como o desrespeito do princípio da neutralidade e a mistura de notícias e comentários.

Bentele (1994b) conclui, no entanto, que sobretudo as contradições que o receptor percebe entre a realidade midiática e a realidade social podem levar a uma redução da credibilidade. Tais sinais derivam tanto da percepção de contradições entre as informações comunicadas e os fatos quanto das incoerências entre as informações de publicações diferentes sobre o mesmo fato.

Neste caso, pode-se reconhecer diferenças nas definições de objetividade com relação à produção jornalística e a questão epistemológica de um lado e a discussão sobre credibilidade de outro lado. Credibilidade deve ser entendida como atribuição, como algo conferido pelo receptor. Em uma situação social determinada, objetividade é - assim como credibilidade - atribuida, bem como competência ou incompetência. A atribuição de credibilidade está, portanto, ligada à objetividade percebida pelo receptor. Credibilidade não depende da adequação à realidade, de informações corretas de fato, mas sim da estimativa do receptor com relação a esta.

Objetividade em jornalismo do ponto de vista epistemológico e do ponto de vista do receptor se baseiam em duas formas diferentes de veracidade. Como veracidade pode-se entender tanto o empenho de buscar a verdade quanto o "considerar como verdadeiro" (cf. Siep, 2000).

Veracidade não deve ser confundida com verdade, pois "uma declaração verídica, feita com a melhor das intenções, pode ser objetivamente falsa. $E$ podese dizer algo de fato correto com a intenção de enganar, ou seja, dizer a verdade inveridicamente" (Siep, 2000: 927).

A transformação da realidade social em realidade midiática pelo jornalista se diferencia da transformação da realidade midiática em realidade do público. No primeiro caso, há o empenho de buscar a verdade, que está ancorada na investiga- 
que os usuários da mídia atribuem credibilidade a um veículo ou a um meio de comunicação por causa da sua objetividade, sem no entanto esclarecer ao quê estes conceitos se referem.

Neste artigo, pretende-se conceber um instrumentário teórico que possa contribuir para superar este déficit. As reflexões dos autores se concentram no jornalismo, ou seja, no campo da mídia que reivindica para si o papel de mediar informações adequadas à realidade, e no seu público.

Primeiro, busca-se definir objetividade e, tomando-se como parâmetro a adequação das informações à realidade, delimitar este conceito frente a outras regras. Uma vez definido o que objetividade é ou pode ser, analisa-se o conceito de credibilidade. Dentro desta análise, procura-se classificar os diferentes níveis do processo de produção midiática ao qual aquela pode se referir.

A partir de conceitos mais claros, as reflexões se concentram na relação entre adequação à realidade, determinadas noções ou rituais de objetividade e credibilidade. O objetivo é desenvolver hipóteses sobre o tipo de conexão existente entre ambos os fenômenos para futuros estudos empíricos com base em conceitos claramente definidos.

\section{Objetividade}

Objetividade é uma norma central em jornalismo, já que a essência deste está na mediação da realidade (cf. entre outros Kovach und Rosenstiel, 2001). Através da sua pretensão de ser o mediador entre o público e a realidade é que o jornalismo se diferencia de outras atividades midiáticas. Portanto, somente uma noção de objetividade que se posicione com relação a esta questão pode contribuir para que o jornalismo cumpra a sua função de informar e de ajudar o receptor a "encontrar-se" dentro do ambiente em que vive.

Neste contexto, se objetividade for entendida em correlação com a função do jornalismo de mediador da realidade, o conceito deveria ser definido como uma representação adequada da realidade e se referir à relação entre as realidades social (primária) e midiática (secundária) (Bentele, 2008). Esta definição contém uma determinada concepção (epistemológica) de verdade, a de verdade como correspondência. Neste sentido, a frase "a neve é branca" é verdadeira se a neve for de fato branca (Popper, 1984: 44).

A concepção de objetividade associada à de verdade como correspondência parte de alguns pressupostos e traz uma série de conseqüências consigo. Objetividade como uma característica da relação entre realidades midiática e social pressupõe a existência de uma realidade primária, de um mundo exterior que não depende de um sujeito conhecedor para existir (cf. Baumann, 2002: 288; Popper, 1984: 109). O estabelecimento de uma correspondência entre ambas as realidades 
pressupõe também o acesso à realidade primária. Neste ponto, esta concepção de objetividade distancia-se de uma posição construtivista radical.

Por outro lado, a correlação entre realidades midiática e social não deve ser entendida como "espelhamento", mas sim como algo gradual (Bentele, 2008), já que não é possível possuir a verdade, só é possível aproximar-se dela (Popper, 1984: 44).

A realidade midiática é o resultado do processo de produção do conhecimento do jornalismo, que tem como ponto de partida o conhecimento do jornalista sobre a realidade. Conhecimento resulta sempre de um "jogo" entre sujeito e objeto, do processamento dos conteúdos vivenciados pelo primeiro (cf. Sponholz, 2007). Neste sentido, o resultado de um processo de conhecimento não é nem espelhamento, nem invenção ou construção, mas sim uma reconstrução da realidade (Bentele, 1993: 160).

Objetividade como adequação à realidade pressupõe a possibilidade de dizer se as informações contidas em uma declaração condizem com a realidade ou não. No entanto, esta possibilidade se limita a declarações descritivas (Bentele, 1988: 219), como por exemplo "O presidente renunciou". Declarações evaluativas ("O presidente é ruim”) ou prescritivas (“O presidente deve renunciar”) não podem ser confrontadas com a realidade segundo critérios intersubjetivos (cf. também Rokeach, 1968).

Isto significa concretamente que é possível dizer qual candidato recebeu o maior número de votos nas eleições para presidente, qual a cotação do dólar hoje e qual o índice de desemprego em uma determinada região. Em todos estes casos, não se trata de fenômenos ou objetos naturais, mas sim de acontecimentos construídos socialmente. A existência destes objetos da realidade construída socialmente não depende da percepção de cada jornalista (Bentele, 2008) e nem mesmo de um observador específico (Searl, 2004: 141). Isto significa que tanto a correlação quanto as contradições de uma declaração descritiva com os objetos descritos podem ser a princípio (epistemologicamente) identificadas.

A principal conseqüência desta concepção é de que a adequação à realidade só pode ser constatada através da confrontação de uma declaração descritiva com a realidade primária, ou seja, através de verificação empírica, e não através de uma separação ou tentativas de anulação do sujeito conhecedor. Considerando-se o exemplo citado, o teor de verdade da frase "a neve é branca" depende dos resultados de uma observação, e não do sujeito que a formulou.

Popper escreveu com relação à objetividade na ciência que "é completamente equivocado acreditar que a objetividade da ciência depende da objetividade do cientista" (Popper, 1993: 112). Por isso Popper define uma teoria como objetiva não através do seu grau de subjetividade, mas sim como "uma teoria que possa ser testada: uma teoria, portanto, que não apele simplesmente para nossas intuições" (Popper, 1979: 200). 
Assim como cientistas, os jornalistas também têm o seu ganha-pão na mediação da realidade (Weischenberg, 1992: 51). Estes estabelecem uma relação entre o que observam e os textos que produzem através da investigação jornalística. Por este motivo, a palavra-chave para a objetividade - quando este princípio é entendido com relação à procura e à aproximação da realidade, à verdade como correspondência - não é neutralidade, mas sim investigação.

\subsection{Rituais de objetividade}

Objetividade em jornalismo não é entendida necessariamente como adequação à realidade nas discussões políticas e cientificas. Trata-se de um conceito polissêmico (Bentele, 1993) freqüentemente associado a tudo o que se deseja do jornalismo ou entende-se como ético (Merrill, 1985).

As pesquisas cientificas em comunicação assumem freqüentemente a imprecisão da linguagem cotidiana sobre este conceito. Às vezes objetividade é entendida como um princípio geral que reúne as regras de abrangência ("tell the whole story"), fairness, equilíbrio, independência, transparência das fontes, separação de notícias e comentários, precisão, imparcialidade, veracidade, neutralidade e foco em fatos (Wyss, 2002: 152; McQuail, 1992: 184; Westerstahl, 1983). Outras vezes, como nos casos das definições operacionais de credibilidade em estudos empíricos (Abdulla et al., 2002; Gaziano, 1988), é colocada lado a lado com accuracy, abrangência, "não ser tendencioso" e fairness. O que significa propriamente objetividade, o que deve ser alcançado com todas estas regras e qual a relação entre estas e a adequação à realidade são questões que permanecem sem respostas.

No entanto, se o objetivo for examinar causas e conseqüências na relação entre objetividade e credibilidade, não se pode adotar a imprecisão da linguagem cotidiana. A análise desta relação exige uma diferenciação clara entre as noções do senso comum e as definições operacionais na mensuração da influência destes rituais de objetividade sobre a credibilidade (dimensão científica).

Noções como fairness, imparcialidade, equilíbrio, neutralidade e foco em fatos são definidas aqui como rituais porque servem não só para proteger jornalistas dos riscos de sua profissão, - como Tuchman (1993) formulou - mas porque também servem para dar credibilidade a um texto ou a um meio de comunicação. Em nenhum destes casos, a adequação das informações mediadas à realidade ocupa um lugar central.

Fairness pode ser entendida como o princípio jornalístico de "ouvir os dois lados" de uma questão (Schudson, 1998: 39). Noções como imparcialidade (impossibilidade de associação do ponto de vista do jornalista ou da publicação com as posições políticas já existentes) e equilíbrio (apresentação das diversas opiniões com o mesmo espaço ou as mesmas chances) acompanham a de fairness (Schönha- 
gen, 1998; Schudson, 1998). Através destas regras, o jornalismo deve cumprir as suas funções social de integração e política de formação e articulação, ao apresentar os pontos de vistas dos defensores de opiniões diferentes e possibilitar o diálogo entre os diversos grupos sociais em uma sociedade de massa.

O cumprimento destas regras não se iguala nem pode substituir a de adequação das informações de uma cobertura jornalística à realidade. Embora fairness possa servir como uma estratégia para averiguar se uma informação é correta (cf. Tuchman, 1993; Fishman, 1980: 117), trata-se de uma alternativa limitada, já que declarações contraditórias não contribuem necessariamente para uma aproximação da realidade. No caso de declarações descritivas ou factuais, é possível que ambas sejam falsas. No caso de declarações não factuais, não é possível verificar se elas são corretas ou não. O estudo de Dolan (2005) sobre a cobertura jornalística de uma obra de arte baseada na imagem de uma santa ilustra esta situação. Se a tal obra é uma blasfêmia ou não, esta não é uma questão de a declaração ser correta ou não. Neste caso, isto não pode necessariamente ser verificado intersubjetivamente.

Além de fairness, objetividade é freqüentemente associada ou igualada com neutralidade e foco em fatos. Estas noções, cuja origem alguns autores localizam no positivismo (Correia, 1998: 102) e outros consideram sem nenhuma sustentação teórica (Benetti/Jacks, 2001; Sousa, 2001), se baseiam na idéia de que o conhecimento da realidade (e com isso a adequação de uma declaração a esta) está ancorado na ausência de subjetividade no processo de conhecimento (Mindich, 1998: 107; Schudson, 1977: 6). Neutralidade e facticidade servem como base para uma "teoria do espelhamento", que é freqüentemente tomada como pressuposto nas discussões sobre objetividade (cf. Donsbach et. al., 1993).

Como neutralidade entende-se a abstenção de expressar opiniões, o que ocorre quando não se consegue reconhecer a opinião do jornalista ou quando este dispensa adjetivos e outras formas de expressão daquela em seu texto. Como facticidade ou foco em fatos entende-se a concentração em declarações descritivas.

$\mathrm{Na}$ discussão sobre objetividade em jornalismo, definições diferentes de fatos se fundem. $\mathrm{Na}$ filosofia, fatos podem ser entendidos (entre outros conceitos) como dados crus recolhidos do mundo exterior ou como uma declaração através da qual tenta-se portar ou transmitir estas informações (Rami, 2004: 77; Keeton, 1942: 124; Langer, 1933: 180). No jornalismo, uma declaração descritiva, através da qual tais dados devem ser mediados, passa a ser tratada como a própria realidade (cf. Gomes, 1993; Schudson, 1977: 6). Com isso, facticidade se transforma em um estilo de redação.

Precisão e separação de notícias e comentários são conseqüências da exigência do foco em fatos. No primeiro caso, a orientação em fatos pressupõe a coleta de dados empíricos (Mindich, 1998: 117). Precisão, no entanto, é mais um instrumento para produzir uma representação adequada da realidade do que um 
conceito de objetividade. Quanto à separação de notícias e comentários, esta resulta de 'faith in ,facts', a distrust of, values', and a commitment to their segregation' (Schudson, 1977: 6).

Nem neutralidade nem facticidade podem ser confundidas com a produção de uma representação adequada da realidade. Não se pode constatar se uma declaração é falsa ou verdadeira através da opinião ou da abstenção do autor em expôla. Como já foi analisado, isto só pode ser constatado através de confrontação com a realidade, de verificação empírica (Meditsch, 1992; Popper, 1994).

Os limites da neutralidade em garantir a mediação de informações condizentes com a realidade se tornaram evidentes na cobertura jornalística sobre as denúncias do senador Joseph McCarthy nos anos 50. Muitos jornalistas (e empresas midiáticas) se abstiveram de expressar sua própria opinião e se limitaram a divulgar as informações que o senador anticomunista forneceu, indiferente do seu teor de realidade (cf. Lane, 2001; Bayley, 1981).

Com relação à facticidade, o foco em fatos e a separação de notícias e comentários podem ser um metacritério de objetividade, necessário para definir se uma declaração é correta. No entanto, "fatos" ou declarações descritivas não são nem neutros nem uma garantia de uma representação adequada da realidade.

Com relação à neutralidade, declarações descritivas podem inclusive ser utilizadas para divulgar opiniões de maneira mais convincente. Assim, ,no conflito publicístico em torno do aborto, a constatação de que embriões de três meses são sensíveis a dor é muito mais eficiente do que a afirmação de que aborto no terceiro mês de gravidez é assassinato", explica Kepplinger (1994: 222).

Quanto ao segundo aspecto, declarações descritivas podem ser falsas. Em setembro de 2006, o jornalista brasileiro Carlos Chagas noticiou na publicação on line Brasília em Dia a fundação de uma organização não-governamental, a Sociedade dos Amigos de Plutão, que se dispunha a lutar pelo estatuto de Plutão como planeta $^{2}$. A notícia contém uma série de elementos descritivos, como por exemplo a informação de que o presidente da entidade é um ex-líder sindical, filiado à CUT e ao PT, amigo íntimo do presidente Lula e a liberação de 7,5 milhões de reais para estimular as primeiras ações da nova ONG. A notícia, que serviu como argumento para a reivindicação de uma Comissão Parlamentar de Inquérito sobre as $\mathrm{ONGs}^{3}$, era falsa: a Sociedade dos Amigos de Plutão nunca existiu, como o próprio Chagas admitiu mais tarde ${ }^{4}$.

\section{Credibilidade}

Dentro da pesquisa sobre credibilidade das fontes (source credibility), orientada na psicologia social e no traballho do grupo de Yale em torno de Carl Hovland (cf.

\footnotetext{
2 Disponível em: <http://www.brasiliaemdia.com.br/2006/9/1/Pagina 744.htm>. Acesso em 20. out. 2008.

3 Disponivelem:<http://www.senado.gov.br/sf/atividade/pronunciamento/detTexto.asp?t $=364338>$. Acesso em 20 out. 2008.
} 
Hovland, Janis e Kelley, 1953), não se definiu claramente o que é credibilidade. Esta foi mensurada sobretudo através dos seus efeitos, geralmente mudanças de atitude. Por este motivo, Berlo, Lemert e Mertz (1969: 565) já defendiam que credibilidade deveria ser entendida como algo a ser conferido ou atribuído e questionaram com isto a definição de "credibilidade da fonte" daquela tradição de pesquisa.

Bentele define credibilidade como "uma característica que alguém (receptores) atribui a pessoas, instituições e seus produtos de comunicação (textos orais ou escritos, apresentações audiovisuais) com relação a algo (acontecimentos, fatos, etc)" (Bentele e Seidenglanz, 2008: 49). Credibilidade não é vista portanto como uma característica inerente do comunicador, mas sim como um fenômeno que surge dentro do processo de comunicação e tem como ponto de partida o outro lado, ou seja, o receptor da informação ou de um texto. Com isso, credibilidade é localizada decididamente do lado do receptor (cf. Bentele e Seidenglanz, 2005).

Köhnken (1990: 4) apresenta uma concepção de credibilidade alternativa ao instalá-la a priori do lado do comunicador. Em vez da percepção do receptor, a intenção do comunicador passa a ser o ponto central: "Credibilidade se dá quando um comunicador transmite uma informação ao receptor, a qual ele acredita que seja correta, ou seja, quando o comunicador não tem a intenção de enganar". Neste caso, credibilidade poderia ser constatada também nos casos em que o emissor se expressa com a intenção de dizer a verdade, mas isto não é interpretado pelo receptor da mesma maneira. Neste contexto, a perspectiva não só é deslocada para o lado do comunicador, como também o receptor sai do foco das atenções.

Isto mostra o problema da proposta de Köhnken, que se refere mais a veracidade (o que o comunicador acredita ser verdade) do que a credibilidade. $\mathrm{O}$ fato de que o receptor possa interpretar o comunicador como alguém credível por causa da intenção deste de transmitir informações verdadeiras pode conter componentes de credibilidade, mas vai contra a validade da definição de Köhnken.

Wirth (1999: 55), por sua vez, concentra-se ainda mais decididamente na figura do receptor quando define credibilidade como uma "disposição a priori de aceitar mensagens de um determinado objeto como corretas e até um determinado ponto adotá-las no próprio espectro de atitudes e opiniões." Credibilidade é acentuada aqui como um processo e sublinha-se o seu aspecto motivacional. No entanto, permanece discutível se a concepção de Wirth contém uma definição de credibilidade em si ou descreve uma conseqüência desta, referindo-se a confiança em vez de credibilidade.

Credibilidade, entendida como uma atribuição de determinadas características ao outro, parte a princípio de uma série de processos cognitivos diferentes (como por exemplo o de fazer experiências e processá-las), mas também tem conseqüências diretas, próprias deste fenômeno, que se expressam por exemplo na pré-disposição em tomar certas atitudes ou ações. 
Também é problemática a delimitação entre os conceitos de credibilidade e de confiança. Na maior parte dos casos, ambos são utilizados de forma não refletida lado a lado ou como sinônimos. Parece mais plausível considerar credibilidade como um fenômeno que faz parte do de confiança (Bentele e Seidenglanz 2005, 346). Confiança e credibilidade formam assim um conglomerado teórico no qual credibilidade é definida mais como algo a ser atribuído pelo receptor, enquanto confiança está ligada ao agir. Esta posiçao possibilita incluir o conhecimento teórico sobre confiança na discussão sobre credibilidade.

\subsection{A hipótese da discrepância}

Segundo Bentele, as contradições de um comunicador percebidas pelo receptor reduzem a sua credibilidade. Ele inclui este aspecto a uma teoria da confiança pública e a define como tese da discrepância, ou seja, 'a percepção de vários tipos de discrepância na comunicação de instituições, pessoas e públicos como uma causa central diretamente responsável por perda de confiança' (Bentele 1994a: 147).

Dentro da hipótese da discrepância, as possíveis variantes das contradições comunicativas em relacionamentos sociais são classificadas como discrepâncias entre:

- Informações comunicadas ou declarações e fatos (mentiras);

- Declarações e ações;

- Ações diferentes da mesma instituição ou de instituições parecidas;

- Declarações diferentes do mesmo autor em momentos diferentes;

- Declarações diferentes de autores diferentes da mesma instituição ou de instituições parecidas;

- Discrepâncias entre as normas gerais ou leis e o comportamento adotado (Bentele, 1994a: 148).

Confiança - e com isso credibilidade - continua sendo vista como características percebidas e interpretadas pelo receptor ('fatores de confiança'). Tais fatores de confiança podem ser, por exemplo, a presença ou ausência de competência específica ou de resolver problemas, mas também responsabilidade social, uma postura ética básica ou transparência (Bentele 1994a: 144).

\subsection{Objetos de referência da credibilidade midiática}

Desde o final dos anos 1950, o parâmetro para os estudos sobre credibilidade na mídia são as pesquisas de opinião representativas do Roper Institut nos Estados Unidos ${ }^{5}$. Nestas pesquisas buscou-se comparar a credibilidade de meios de comunicação diferentes (rádio, televisão, jornais e revistas) ${ }^{6}$.

\footnotetext{
5 A questão na pesquisa de Roper é: 'If you heard conflicting versions of the same story from these sour 7 ces,
which would you be most likely to believe- the one on radio or television or magazines or newspapers?' (Roper, 1978: 222) 6 Os jornais eram o meio com maior credibilidade no primeiro estudo, de 1959. Em 1961, a televisão assumiu este lugar (Roper 1985: 5), situação mantida até hoje. Há vários estudos bascados na mesma pergunta de Roper que ampliaram ou diferenciaram as investigações sobre a credibilidade dos meios (cf. Westley e Severin, 1964).
} 
Para Bentele (2008), a questão é obter resultados sobre aspectos mais profundos da questão da credibilidade midiática ao levantá-los não somente com relação ao meio de comunicação, mas também com relação ao veículo ou programa escolhido. Neste sentido, as diferenças entre credibilidade intramidiática podem ser maiores do que a entre os meios. Nestmann (1980: 116) constatou com relação à TV que programas podem ser avaliados de maneira mais positiva do que o meio em si, o que mostra que esta diferenciação faz sentido. Uma série de trabalhos anteriores fizeram o mesmo analisando a credibilidade de jornais e canais de TV locais (cf. Abel/Wirth, 1977) .

De maneira geral, pode-se dizer que "credibilidade midiática" pode ser atribuída a objetos muito diversos e resultar respectivamente tanto em conceitos quanto mecanismos diferentes de atribuição. O conceito pode conseqüentemente ser analisado em níveis distintos.

Baseando-se em Wirth $(1999,54)$, pode-se diferenciar dois níveis de análise, o do conteúdo ou mensagem concretamente e sua apresentação de um lado e o nível de mediação e do mediador, que podem ser claramente separados considerando-se os diferentes aspectos da atribuição de credibilidade. Esta pode ser conferida a textos, ou seja, a o quê está sendo apresentado ou comunicado ou a quem apresenta ou comunica algo.

O meio de comunicação recebe uma posição especial neste modelo. Este é entendido como o modo de apresentação, ou seja, como se comunica (visual, auditivo, audiovisual) e é classificado dentro dos conteúdos midiáticos. Sua apresentação é entendida como parte da mensagem.

Por outro lado, meios podem ser entendidos como parte das instituições de mediação, como por exemplo televisão como o conjunto dos canais. Quando se trata de credibilidade, ambos podem ser importantes, mas aqui prefere-se o entendimento de meios como modo de apresentação (veja gráfico 1).

A investigação de credibilidade midiática baseada unicamente no meio de comunicação (televisão, rádio, jornal ou revista) já foi criticada várias vezes. Não se confere credibilidade à televisão ou à revista, mas sim a um determinado canal ou uma determinada revista. O meio como o único objeto de credibilidade midiática e conseqüentemente de investigação é problemático a priori quando o meio é entendido como a categoria geral dentro da qual as instituições midiáticas são organizadas. Isto é questionável se for considerada a heterogeneidade, que abrange desde o programa de entretenimento até o canal com temas específicos.

O ponto de investigação relevante para a credibilidade midiática se encontra na apresentação dos conteńdos específica de cada meio (cf. Christofoletti e Laux, 2008). Por isso, apesar da crítica, a diferenciação de credibilidade de acordo com o meio é indispensável. A imprensa tem uma outra recepção do que o rádio ou 
a TV, o que influencia a credibilidade que lhe é conferida. A televisão tem uma credibilidade maior do que a imprensa, pois aquela dá ao receptor a impressão de que os acontecimentos podem ser controlados por causa das possibilidades de visualização (Bentele, 2008) . $^{8}$

Ao lidar com a mídia, são os conteúdos que interessam ao receptor e que oferecem a possibilidade de integração de ações e mudanças de atitude. Como conteúdos entende-se os acontecimentos ou fatos apresentados. Pertencem a eles atores como políticos ou empresários, cujas declarações ou ações fazem parte das mensagens midiáticas, mas que não pertencem ao sistema midiático. $O$ conceito de credibilidade midiática envolve com isso basicamente a credibilidade da apresentação, que deve ser diferenciada daquela dos atores apresentados.

A credibilidade dos textos, do seu conteúdo, depende das características do texto, sobretudo de até que ponto percebe-se contradições entre os seus elementos e entre declarações diferentes. Também neste caso deve-se diferenciar entre as contradições do ator apresentado no texto e do texto próprio. Se uma notícia apresenta contradições entre as declarações de um ator, esta é uma questão de credibilidade do autor, e não do conteúdo midiático. Para a credibilidade do texto, o relevante é o último, ou seja, incoerências dentro de um texto ou entre textos diferentes. Além disso, o decisivo é até que ponto o receptor percebe tais contradições.

A credibilidade dos conteúdos ou das formas de apresentação destes por um lado e da dos diferentes níveis de mediação, responsável pela transmissão dos conteúdos de outro lado, se influenciam reciprocamente. A credibilidade do comunicador condiciona a priori a de um conteúdo concreto.

Com relação às instâncias de mediação, pode-se diferenciar diferentes camadas ou niveis, aos quais credibilidade pode ser conferida: pessoal, institucional e do sistema. Este conceito considera o resultado do desenvolvimento histórico, da constituição e da profissionalização da mídia. Desta forma, o elemento de uma camada parte da anterior, aumentando a complexidade e abstração.

A separação clássica entre pessoa, instituição e sistema ${ }^{9}$ é necessária para uma classificação dos possíveis de credibilidade midiática porque, dependendo do grau de abstração, alguns mecanismos de atribuição de credibilidade se tornam mais relevantes do que outros. A credibilidade de uma determinada pessoa se baseia em aspectos diferentes do que a avaliação de instituições ou sistemas.

A credibilidade das pessoas na mídia pode ser identificada como a camada mais concreta. No caso da credibilidade concedida "cara a cara", a semelhança que o receptor pensa ter com o personagem da mídia é um destes fatores. Esta semelhança tem sido investigada sobretudo com relação à semelhança cultural

8 Um telespectador pode acompanhar o que acontece nas telas, ou pelo menos acredita nisto. Ele pode participar diretamente do acontecimento. A característica da visualidade, especifica deste meio, tem um papel altamente relevante para a atribuição de credibilidade.

9 Esta classificação é feita também por Bentele (1994a: 143) com relação ao problema da confiança. 
ou ao pertencimento à mesma nacionalidade (cf. Miller/Hoppe, 1973) ou com relação à concordância com os mesmos juízos de valor ${ }^{10}$. No último caso, podem ser analisadas não somente pessoas, mas também instituições.

No entanto, faz sentido separar a credibilidade das pessoas na mídia daquela das instituições midiáticas. No caso da avaliação das pessoas, os mecanismos aprendidos desde a infância, através dos quais pode-se analisar a credibilidade de uma pessoa, e a veracidade conferida a um apresentador com base nas correlações de comportamento ganham uma importância maior (cf. Köhnken 1990: 10). No caso de instituições, trata-se sobretudo da sua funcionalidade, das regras e do controle que devem garantir o cumprimento desta função.

O último tipo de objeto do lado daquele que carrega a mensagem, do mediador, é o sistema midiático. Credibilidade refere-se neste caso à mídia ou ao jornalismo. Trata-se de uma avaliação generalizada ao comportamento da mídia e de jornalistas e da sua credibilidade. Tais estudos se tornam relevantes sobretudo quando se argumenta sobre a função social do jornalismo. No nível do sistema midiático, credibilidade se baseia na condensação de experiências anteriores e da respectiva generalização destas experiências, sendo visivelmente mais estável do que a dos demais objetos. 
Gráfico 1: Objetos de credibilidade midiática

Atribuiçăo de credibilidade

Mediador/comunicador

Conteúdos e sua apresentação
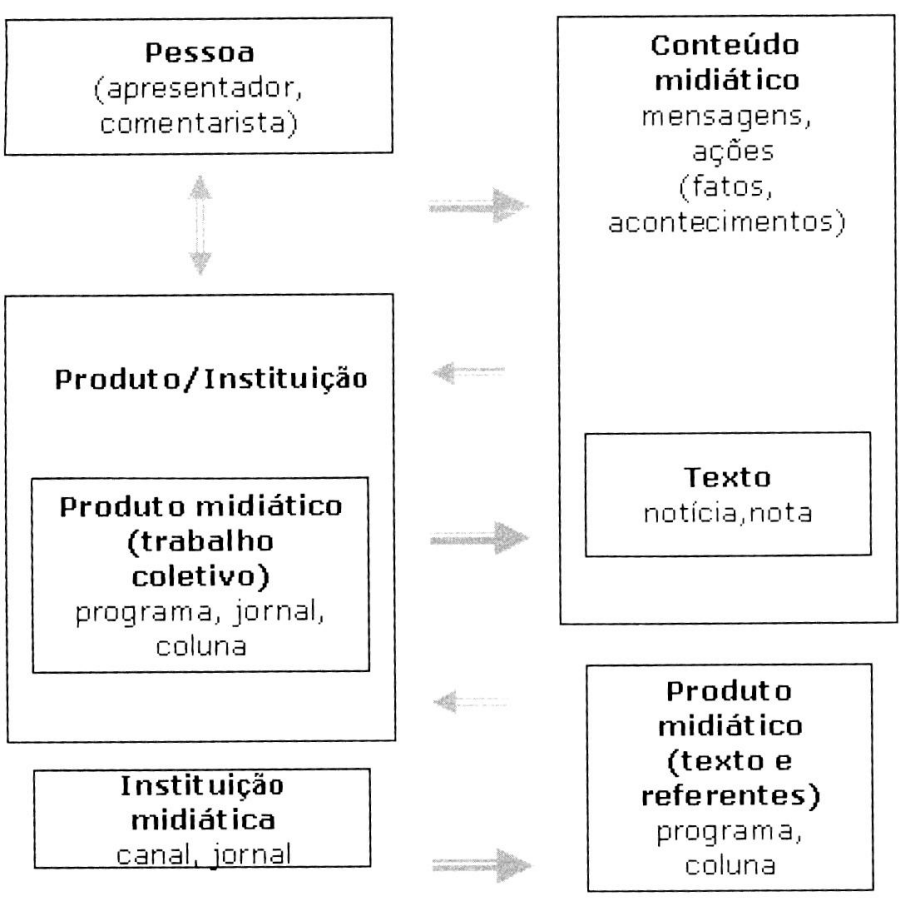

Produto midiático

(trabalho

coletivo)

programa, jornal, coluna
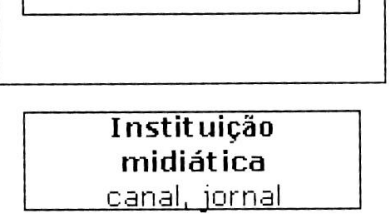

Sistema

(mídia, jornalismo)

\section{Meio}

TV, Rádio, Internet 


\section{Credibilidade midiática e objetividade}

Objetividade tem sido analisada como um dos componentes da dimensão "trutsworthiness" nos estudos voltados para a análise multidimensional de credibilidade (cf. entre outros Mosier e Ahlgren, 1981). Hovland, Janis e Kelley (1953), por sua vez, ordenaram o fator de objetividade ao lado do conceito de honestidade (bonesty). Já Whitehead (1968), Iyengar e Kinder (1985) e Austin e Dong (1994) investigam objetividade como um componente separado de credibilidade.

Caso deva-se formular uma relação de causalidade entre credibilidade e objetividade, considerando-se as pesquisas já realizadas, faz sentido postulá-la na direção da objetividade - como o receptor a percebe - para a credibilidade.

Neste contexto, Bentele (2008: 248) constata uma correlação entre determinados "standards de objetividade" na mídia e na cobertura jornalística e a credibilidade destas publicações junto à população. Nos casos das publicações em que há um alto grau de julgamentos feitos pelos próprios jornalistas, observa-se um grau de credibilidade tendencialmente mais baixo. Bentele (2008) cita sinais concretos que são interpretados pelo receptor como falta de objetividade como o desrespeito do princípio da neutralidade e a mistura de notícias e comentários.

Bentele (1994b) conclui, no entanto, que sobretudo as contradições que o receptor percebe entre a realidade midiática e a realidade social podem levar a uma redução da credibilidade. Tais sinais derivam tanto da percepção de contradições entre as informações comunicadas e os fatos quanto das incoerências entre as informações de publicações diferentes sobre o mesmo fato.

Neste caso, pode-se reconhecer diferenças nas definições de objetividade com relação à produção jornalística e a questão epistemológica de um lado e a discussão sobre credibilidade de outro lado. Credibilidade deve ser entendida como atribuição, como algo conferido pelo receptor. Em uma situação social determinada, objetividade é - assim como credibilidade - atribuida, bem como competência ou incompetência. A atribuição de credibilidade está, portanto, ligada à objetividade percebida pelo receptor. Credibilidade não depende da adequação à realidade, de informações corretas de fato, mas sim da estimativa do receptor com relação a esta.

Objetividade em jornalismo do ponto de vista epistemológico e do ponto de vista do receptor se baseiam em duas formas diferentes de veracidade. Como veracidade pode-se entender tanto o empenho de buscar a verdade quanto o "considerar como verdadeiro" (cf. Siep, 2000).

Veracidade não deve ser confundida com verdade, pois "uma declaração verídica, feita com a melhor das intenções, pode ser objetivamente falsa. E podese dizer algo de fato correto com a intenção de enganar, ou seja, dizer a verdade inveridicamente" (Siep, 2000: 927).

A transformação da realidade social em realidade midiática pelo jornalista se diferencia da transformação da realidade midiática em realidade do público. No primeiro caso, há o empenho de buscar a verdade, que está ancorada na investiga- 
ção jornalística, na averigüação das informações. Veracidade do ponto de vista da produção jornalística ultrapassa o nível da intenção de dizer a verdade por causa da obrigação de uma investigação rigorosa.

Com certeza, nem o jornalista nem o receptor possuem a verdade sobre um acontecimento. Mas o jornalista tenta pelo menos estabelecer uma relação entre realidade midiática e realidade social. No caso do receptor, é plausível que ele pressuponha a existência desta relação. Deste modo, a veracidade do ponto de vista do receptor consiste em "considerar como verdadeiro" (gráfico 2).

$O$ fato de o receptor partir do que considera como verdadeiro e não do que o é de fato não deve ser confundido com uma postura radical construtivista, segundo a qual a atribuição de objetividade e de credibilidade são constituídas arbitrariamente pelo receptor ou com base em critérios individuais.

A recepção da mídia ocorre certamente segundo os esquemas aprendidos individualmente, mas esta não pode ser pensada sem ter alguma relação com a realidade. Estimativas sobre a objetividade de um texto são provavelmente construídas em parte pelo receptor, mas não de forma arbitrária. A base para considerar algo como verdadeiro é sempre algum tipo de ligação com a realidade.

No entanto, as dificuldades do receptor de averiguar se informações são corretas aumentam no caso do conhecimento factual. Esta averiguação constitui a atividade central do jornalismo. Tratando-se de tal conhecimento, o receptor só consegue perceber equívocos de forma limitada. Isto ocorre não porque é impossível saber - do ponto de vista epistemológico - se uma declaração descritiva corresponde à realidade, mas sim porque por motivos organizacionais o receptor comum não pode (ou mesmo quer ou precisa) averiguar fatos.

Se por um lado é difícil constatar déficits na adequação da cobertura jornalística à realidade no conhecimento factual, por outro lado, quando estes são constatados, as empresas de comunicação e os jornalistas enfrentam problemas sérios em virtude da perda de credibilidade.

Este foi o caso de Janet Cooke e do jornal Washington Post. Em 1981, Cooke inventou uma história sobre um garoto de oito anos viciado em cocaína. "Jimmy's World" alcançou as manchetes do Washington Post e a sua autora recebeu até mesmo o prêmio Pulitzer. A história só se revelou como farsa depois da repercussão da "reportagem" e a busca por Jimmy desencadeada por esta. O jornal teve que enfrentar na época a queda do valor das suas ações na Bolsa de Valores (Anderson, 2004).

O princípio da credibilidade funciona nestes casos como um peso contrário às manipulações grosseiras e às tendências manipulativas das fontes de informação (como por exemplo assessorias de imprensa e departamentos de relações públicas de instituições privadas e públicas) e da mídia. A falta de credibilidade nas informações têm no mínimo a médio prazo conseqüências negativas para as organizações envolvidas (Bentele 2008: 316). 
Veracidade é, ao lado da pressuposição de competência da fonte, um dos aspectos essenciais de credibilidade. O pressuposto da veracidade é um motivo decisivo para que credibilidade seja atribuída a um meio, a um veículo, a um comunicador ou a uma mensagem.

Credibilidade, no entanto, não se deixa reduzir a uma representação adequada da realidade. Em outras palavras, receptores não consideram uma informação verdadeira unicamente porque ela de fato o é. A atribuição de veracidade a um texto depende de uma série de fatores como o tipo de meio, à instituição e ao próprio comunicador.

Objetividade e credibilidade envolvem respectivamente o conteúdo e da sua apresentação (gráfico 3). Do ponto de vista da objetividade, a questão é se o texto apresenta uma representação adequada da realidade (conteúdo). Quanto à apresentação, o que está em jogo não é a objetividade (adequação à realidade), mas sim rituais de objetividade como neutralidade, fairness, equilíbrio ou facticidade. Um texto sem julgamentos explícitos, a mediação de pontos de vista contraditórios ou um texto com uma concentração maior em declarações descritivas são sinais que podem levar o receptor a considerar os conteúdos verdadeiros.

Estes sinais possibilitam ao receptor concluir se a fonte se empenha em dizer a verdade. Ele utiliza estes instrumentos de ajuda para identificar mensagens e emissores, pois o seu acesso direto às informações é em grande parte velado. Com a ajuda destes sinais, ele tenta compensar este déficit.

Gráfico 2: Delimitação dos problemas

Objetividade

Crediblidade

Veracidade como

Principio empenho na busca da
verdade

Veracidade como „Considerar como verdadeira" 


\section{Gráfico 3: Relaçăo entre objetividade e credibilidade}

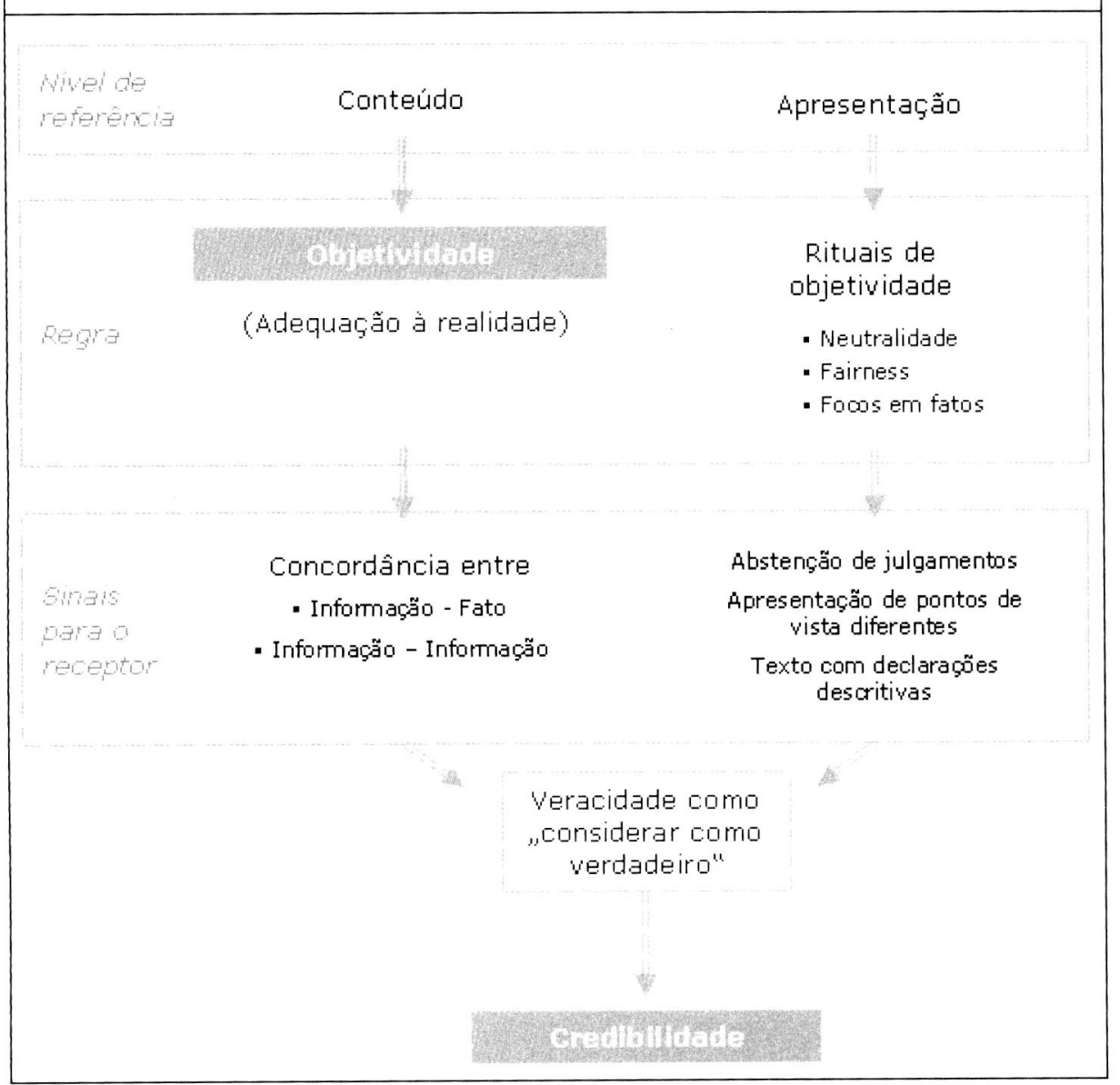

5. Conclusões

Objetividade pode ser definida como a adequação da realidade midiática à realidade social, mas o que importa para a atribuição de credibilidade é como o receptor avalia esta adequação ${ }^{11}$. Neste sentido, o que determina a sua atribuição de credibilidade não é até que ponto as informações de fato são corretas, mas sim até que ponto ele estima que as informações sejam corretas.

Portanto, credibilidade não se reduz à adequação das informações comunicadas à realidade. Pode-se também supor que, nas suas experiências diárias com a mídia, rituais de objetividade como neutralidade, fairness ou equilíbrio sejam mais importantes para a atribuição de credibilidade do que a adequação à realidade, que o receptor pressupõe e/ou freqüentemente só pode estimar (através de coerência 
ou ausência de contradições). Neste sentido, o problema da objetividade só tangencia o da credibilidade. Considerando-se a análise desenvolvida neste artigo, esta ligação deve ser vista dentro de um modelo processual que a localize dentro dos sinais recebidos e percebidos pelo receptor e da atribuição de veracidade. 


\section{Referências Bibliográficas}

ABDULLA, R. A. et al. The Credibility of Newspapers, Television News, and Online News. Proceedings... Miami Beach: Association for Education in Journalism and Mass Communication Annual Convention, 2002.

ABEL, John D.; WIRTH, Michael O. Newspaper vs. TV Credibility for Local News. Journalism Quarterly, v. 54, n. 2, p. 371-375, Summer 1977.

ANDERSON, William L. Facts, Fiction and the Fourth Estate. The Washington Post and "Jimmy's World". The American Journal of Economics and Sociology, v. 63, n.5, p. 965-986, November 2004.

AUSTIN, Erika W.; DONG, Quingwen. Source v. Content Effects on Judgements of News Believability. Journalism Quarterly, v. 71, n. 4, p. 973-983, Winter 1994.

BAUMANN, Peter. Erkenntnistheorie: Lehrbuch Philosophie. Stuttgart, Weimar: Metzler, 2002.

BAYLEY, Edwin. Joe Mc Carthy and the Press. New York: Pantheon Books, 1981.

BENETTI, Marcia; JACKS, Nilda Aparecida. O discurso jornalístico. In: Anais... Brasília: Associação Nacional dos Programas de Pós-Graduação em Comunicação, 2001. v. 1. p. 280-290.

BENTELE, Günter. Wie objektiv können Journalisten sein? In: ERBRING, Lutz; RUB-MOHL, Stephan (org). Medien obne Moral. Variationen über Journalismus und Ethik. Berlin: Argon-Verlag, 1988, p. 196-225.

Wie wirklich ist die Medienwirklichkeit? Einige Anmerkungen zum Konstruktivismus und Realismus in der Kommunikationswissenschaft. In: BENTELE; Günter; RÜHL, Manfred (org). Theorien öffentlicher Kommunikation. München: Ölschläger, 1993, p. 152-171.

Öffentliches Vertrauen- normative und soziale Grundlagen für Public Relations. In: ARMBRECHT, Wolfgang/ZABEL; Ulf (org). Normative Aspekte der Public Relations. Opladen: Westdeutscher Verlag, 1994a, p. 131-158.

Objektivitätsanspruch und Glaubwürdigkeit. In:JARREN, Otfried (org). Medien und Journalismus 1. Eine Einführung. Opladen: Westdeutscher Verlag, 1994b, p. 296-313.

SEIDENGLANZ, René. Vertrauen und Glaubwürdigkeit. In: BENTELE, Günter; FRÖHLICH, Romy; SZYZKA, Peter (Hg.). Handbuch der Public Relations. Wiesbaden: Verlag für Sozialwissenschaften, 2005, p. 346-360.

Objektivität und Glaubwürdigkeit: Medienrealität rekonstruiert. Herausgegeben und eingeleitet von Stefan Wehmeier, Howard Nothhaft und René Seidenglanz. Wiesbaden: VS, 2008.

SEIDENGLANZ, René. Trust and Credibility - Prerequisites for Communication Management. In: ZERFASS, Ansgar; RULER, B. van; SRIRAMESH, K. Sriramesh (org). Public Relations Research. European and International Perspectives and Innovations. Wiesbaden: VS Verlag für Sozialwissenschaften, 2008, p. 49-62. 
BERLO, David K.; LERNERT, James B. ; MERTZ, Robert J. Dimensions for Evaluating the Acceptability of Message Sources. Public Opinion Quarterly, v. 33, n. 4, p. 563-576, Fall 1969.

CORREIA; José Carlos. Jornalismo e espaço público. Covilhã: Universidade da Beira Interior, 1998. Disponivel em: <http://www.labcom.ubi.pt/livroslabcom/ pdfs/correia_jornalismo_espacopublico.pdf >, Acesso em 20 out. 2008.

CHRISTOFOLETTI, Rogério; LAUX, Ana Paula França. Confiabilidade, credibilidade e reputação: no jornalismo e na blogosfera. Revista Brasileira de Ciências da Comunicação, v. 31, n. 1, p. 29-49, jan-jun. 2008.

DOLAN, Kevin. Blinded by „objectivity“. How news conventions caused journalists to miss the real story in the "Our Lady" controversy in Santa Fe. Journalism Studies, vol. 6, n. 3, p. 379-396, August 2005.

DONSBACH, Wolfgang; BROSIUS, Hans-Bernd; MATTENKLOTT, Axel. Die zweite Realität. Ein Feldexperiment zur Wahrnehmung einer Wahlkampfveranstaltung durch Teilnehmer und Fernsehzuschauer. In: HOLTZ-BACHA; Christina; KAID, Lynda Lee (org). Die Massenmedien im Wablkampf. Untersucbungen aus dem Wabljahr 1990. Opladen: Westdeutscher Verlag, 1993, p. 185-207.

FISHMAN, Mark. Manufacturing the News. Austin, London: University of Texas Press, 1980.

GAZIANO, Cecilie. How credible is the credibility crisis? Journalism Quarterly, vol. 65, n. 2, p. 267-278, Summer 1988.

GOMES, Wilson. Verdade e Perspectiva. A questão da verdade e o fato jornalístico. Textos de Cultura e Comunicaşão, n.29, p. 63-83, 1993.

HOVLAND, Carl I.; JANIS; Irving L.; KELLEY, Harold H. Communication and Persuasion. Psychological Studies of Opinion Change. New Haven/London: Yale University Press, 1953.

IYENGAR, Shanto; KINDER, Donald R. Psychological Accounts of Agenda-Setting. In: KRAUS, Sidney; PERLOFF, Richard M. (org): Mass Media and Political Thought. An Information-Processing Approach. Beverly Hills/London/New Delhi: Sage, 1985, p. 117-140.

KEETON, Morris T. On Defining the Term „Fact“. The Journal of Philosophy, v. 39, n. 5 , p. $123-132,1942$.

KEPPLINGER, Hans Mathias. Publizistische Konflikte. Begriffe, Ansätze, Ergebnisse. Kölner Zeitschrift für Soziologie und Sozialpsychologie, Sonderheft 34, Jg. 46, p. 214-233, 1994.

KÖHNKEN, Günter. Glaubwürdigkeit. Untersuchungen zu einem psychologischen Konstrukt. München: Psychologie Verlags Union, 1990.

KOVACH, Bill; ROSENSTIEL, Tom The elements of Journalism. What Newspeople Should Know and the Public Should Expect. New York: Crown Publishers, 2001. 
LANE, Les. A Reexamination of the Canon of Objectivity in American Journalism. Disponível em: <http://etd.lsu.edu/docs/available/etd-1114101-191429/unrestricted/Lane_thesis.pdf>. Acesso em 20 out. 2008.

LANGER, Susanne. Facts: The Logical Perspectives of the World. The Journal of Pbilosophy, v. 30, n. 7, p. 178-187, 1933.

MCCAIN, Thomas A.; CHILBERG, Joseph; WAKSHLAG, Jakob. The Effect of Camera Angle on Source Credibility and Attraction. Journalism Quarterly, v. 55, n. 2, p. 282-287, Fall 1977.

MCQUAIL, Denis. Media performance. Mass communication and the public interest, London, Newbury Park, Calif., Sage Publications, 1992.

MEDITSCH, Eduardo. O Conbecimento do Jornalismo. Florianópolis: Editora da UFSC, 1992.

MERRILL, John C. Is Ethical Journalism Simply Objective Reporting? Journalism Quarterly, v. 62, 391-393, Summer 1985.

MILLER, Dale T.; HOPPE, Ronald A. The Effect of Regional Similarity-Dissimilarity on Communicator Credibility. Language and Speech, v. 16, p. 211-217, 1973.

MINDICH, David T.Z. Just the Facts: How "Objectivity" came to define American Journalism. New York: New York University Press, 1998.

MOSIER, Nancy R.; AHLGREN, Andrew. The Credibility of Precision Journalism. Journalism Quarterly, v. 58, p. 375-381, 1981.

NAWR ATIL, Ute. Glaubwürdigkeit in der sozialen Kommunikation. Opladen: Westdeutscher Verlag, 1997.

NESTMANN, Frank. Fernsehen im Urteil der Zuschauer. Eine empirische Analyse von Medienkritik und Medienbewußtsein. Tübingen: Niemeyer, 1980.

PATERSON, Maggie Jones; URBANSKI, Steve. What Jayson Blair and Janet Cooke say about the press and the erosion of public trust. Journalism studies, vol. 7, n. 6, p. 828-850, Dezember 2006.

POPPER, Karl. Ausgangspunkte. Meine intellektuelle Entwicklung. Hamburg: Hoffmann und Campe, 1979.

. Objektive Erkenntnis. 4. ed. Hamburg: Hoffman und Campe, 1984.

. Die Logike der Sozialwissenschaften. In: Adorno, Theodor W. et al. Der Positivismusstreit in der deutschen Soziologie. 3. ed. München: dtv wissenschaft, 1993, p. 103-125.

. Logik der Forschung. 10. ed. Tübingen: Mohr, 1994.

RAMI, Adolf. Why the Minimalist Cannot Reduce Facts to True Propositions. Metaphysica, n. 1, p. 77-83, 2004.

ROKEACH, Milton. Beliefs, Attitudes and Values: A Theory of Organization and Change. San Francisco: Jossey-Bass, 1968.

ROPER, Burns W. Changing Public Attitudes toward Television and Other Media 1959-1976. Communications, v. 4, p. 220-238, 1978. 
ROPER, Burns W. Public Attitudes Toward Television And Other Media In a Time of Change. New York: Television Information Office, 1985.

SCHÖNHAGEN, Philomen. Unparteilichkeit im Journalismus: Tradition einer Qualitätsnorm. Tübingen: Niemeyer, 1998.

SCHUDSON, Michael. Discovering the News: A Social History of American Newspapers. New York: Basic Books, 1977.

. In All Fairness. In: Giles, Robert; Snyder, Robert. What's fair? The problem of equity in journalism. Media studies journal, spring/summer 1998, p. 34-41, 1998.

SEARL, John R. Geist, Sprache ind Gesellschaff. Frankfurt a. M.: Suhrkamp, 2004.

SIEP, Ludwig. Wahrheit und Wahrhaftigkeit in der Philosophie. Zentralblatt für Chirurgie, v. 11, n. 125, p. 926-930, November 2000.

SIMONS, Herbert W.; BERKOWITZ, Nancy N. ; MOYER; R. John. Similarity, Credibility, and Attitude Change A Review and a Theory. Psychological Bulletin, v. 73, p. 1-16, 1970.

SOUSA, Jorge Pedro. Elementos do jornalismo impresso. Biblioteca On-line de Ciências da Comunicação. Disponível em: < http://bocc.ubi.pt/pag/sousa-jorgepedro-elementos-de-jornalismo-impresso.pdf $>$. Acesso em 20 out.2008.

SPONHOLZ, Liriam. Entre senso comum e ciência: o conhecimento híbrido do jornalismo. Ciências \& Cognição, ano 4, vol. 10, 1-14, mar. 2007. Disponível em <http://www.cienciasecognicao.org/artigos/v10/317140.html $>$.Acesso em 20 out. 2008.

TAMBOSI, Orlando. Jornalismo e teorias da verdade. Revista Brasileira de Ciências da Comunicaşão, v. 30, n. 1, p. 35-48, jan.-jun. 2007.

TUCHMAN, Gay. A objectividade como ritual estratégico: uma análise das noções de objectividade dos jornalistas. In: Traquina, Nelson. Jornalismo: questões, teorias e "estórias". Lisboa: Vega, 1993, p. 74-90.

WEISCHENBERG, Siegfried. Journalistik. Theorie und Praxis aktueller Medienkommunikation. Band I: Mediensysteme, Medienethik, Medieninstitutionen. Opladen: Westdeutscher Verlag, 1992.

WESTERSTAHL, Jörg. Objective News Reporting. Communication Research, v. 10, n. 3, p. 403-424, 1983.

WESTLEY, Bruce H.; SEVERIN; Werner J. Some Correlates of Media Credibility. Journalism Quarterly, 41, n. 2, p. 325-335, 1964.

WHITEHEAD, Jack L., Jr. Factors of Source Credibility. Quarterly Journal of Speech, v. 54, p. 59-63, 1968.

WIRTH, Werner. Methodologische und konzeptionelle Aspekte der Glaubwürdigkeitsforschung. In: RÖSSLER, Patrick; WIRTH, Werner (org). Glaubwürdigkeit im Internet. Fragestellungen, Modelle, empirische Befunde. München: R. Fischer, 1999, p. 47-66.

WYSS, Vinzenz. Redaktionelles Qualitätsmanagement: Ziele, Normen, Ressourcen. Konstanz: UVK, 2002. 